\title{
PALEODIET RECONSTRUCTION OF HUMAN REMAINS FROM THE ARCHAEO- LOGICAL SITE OF NATFIEH, NORTHERN JORDAN
}

\author{
Khaled Al-Bashaireh ${ }^{1}$ Abdullah Al-Shorman ${ }^{2}$ Jerome Rose $^{3} \bullet$ A J Timothy Jull ${ }^{4}$ \\ Gregory Hodgins ${ }^{4}$
}

\begin{abstract}
This investigation concerns human teeth and bones from the site of Natfieh, north Jordan. Nitrogen and carbon isotope analyses were used to model the paleo-economy by reconstructing Natfieh's paleodiet during a specific time period. ${ }^{14} \mathrm{C}$ dating of human teeth and bones from the site of Natfieh, north Jordan, demonstrate that they belong to the Early Roman period and match the archaeological date from the tomb and grave goods typology. Stable isotope analyses of these humans have provided new information about the subsistence and society of individuals buried at Natfieh. Natfieh is today agriculturally productive and must have been so in antiquity with most of the foodstuffs having been produced locally. The long distance between Natfieh and the closest aquatic food source (Mediterranean Sea and Lake Tiberias) and the high cost of land transportation might be the reason for the low consumption of marine protein. The results agree with past research on the Roman diet showing that plants were the common source of food for the Romans and fish may have been restricted to elite members of the society.
\end{abstract}

\section{INTRODUCTION}

In areas where the benefits of centralization are limited, coupled with taxation and diminished resources, a local economy has to be adjusted to an optimal level where people can survive and reproduce (Finley 1999). The rural areas in Jordan during the Roman period (63-324 CE), or even $150 \mathrm{yr}$ earlier (Freeman 2001) are reconstructed as having a self-sufficient economy. The populace utilized local crops, small industries, and trade to fulfill their basic needs with a few elites accumulating more wealth (Kingsley 2001). The collective economy of Roman rural sites in Jordan was more than modest and probably contributed to the overall economy of the empire. Rose et al. (2007) postulated that rural Roman sites enjoyed economic prosperity. They attribute this prosperity to the sites' agricultural productivity, small product industry, and the general well-being of the inhabitants. However, the factors that probably contributed to the accumulation of wealth are site-specific and may not apply at other contemporaneous sites (Grossman 1974). The site of Natfieh is not on one of the major trade roads and the cost of land transportation was relatively high (Freeman 2001). Consequently, the site of Natfieh may represent an exception to this model. The current study models aspects of the paleoeconomy of the Natfieh site by reconstructing the paleodiet using isotopic analysis of human bones and teeth.

The archaeological site of Natfieh is located $\sim 5 \mathrm{~km}$ southwest of Irbid, in the north of Jordan (see Figure 1). It was excavated in 2006 and 2007 through a tripartite cooperation between Yarmouk University, the University of Arkansas, and the Department of Antiquities of Jordan, to explore the rural economy's impact on the health of the lower social class. All of the horizontal shaft tombs are Roman in their typology, follow the rock formation outcrop in their location, and are far from the residential area, consistent with prevailing Roman tradition (Toynbee 1996). Tomb investigations reported the existence of horizontal shaft (single) tombs and large horizontal chambers of multiple tombs. One of these chambers has a nicely carved door and doorway. It is proposed that a greater amount of energy was expended at the burials of the high social ranking individuals (Trainter 1975).

\footnotetext{
${ }^{1}$ Department of Archaeology, Yarmouk University, Postal code 211-63, Irbid, Jordan.

${ }^{2}$ Department of Anthropology, Yarmouk University, Postal code 211-63, Irbid, Jordan.

${ }^{3}$ Dept. of Anthropology, Old Main 330, University of Arkansas, Fayetteville, Arkansas 72701, USA.

${ }^{4}$ NSF-Arizona Accelerator Mass Spectrometry Laboratory, University of Arizona, Tucson, Arizona 85721, USA.
}

(C) 2010 by the Arizona Board of Regents on behalf of the University of Arizona Proceedings of the 20th International Radiocarbon Conference, edited by A J T Jull RADIOCARBON, Vol 52, Nr 2-3, 2010, p 645-652 
The differences of Natfieh tombs might indicate the existence of 2 different social classes at the site: the general public and the elites. El-Najjar et al. (2008) mentioned that the diet of the 2 individuals buried in a flexed position in tombs $46 \mathrm{~A}$ and $46 \mathrm{~B}$ might differ from the diet of the other individuals buried in the other tombs in an extended position. They have hypothesized that the diet consumed by a population living in the same time period varied by social class. Due to the robbing of these tombs in antiquity and modern times, the few burial offerings found cannot refute or support this hypothesis.

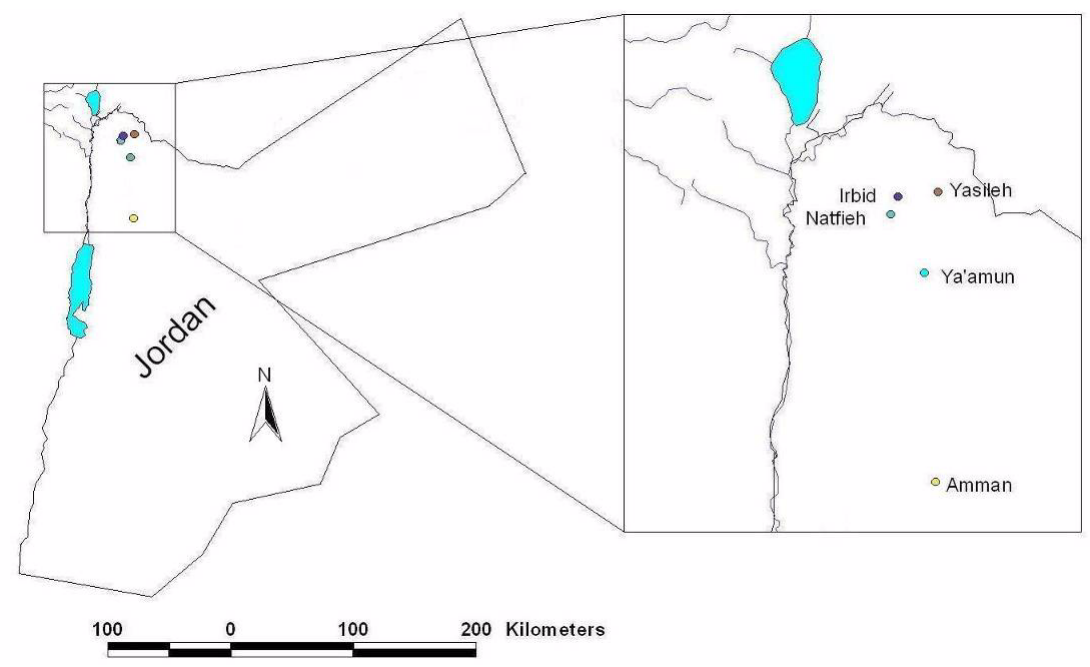

Figure 1 Map of Natfieh

Analysis of the stable carbon and nitrogen isotopes of human collagen is a reliable method for reconstructing the paleodiet, which can reveal the sources of protein in human diet. Collagen is produced mainly from dietary protein, whereas bone apatite and tooth enamel are produced from the whole diet (Ambrose and Norr 1993; Tieszen and Fagre 1993). On the other hand, collagen contains a longer record of an individual's diet compared to enamel, which represents largely the period of early childhood (Schwarcz and Schoeninger 1991; Ambrose 1993; Sealy 2001; Thompson et al. 2005; Tykot 2006).

Isotopic composition of carbon and nitrogen in the human body tissues reflects that of the consumed food. Plants, for example, have 2 main photosynthetic pathways, $\mathrm{C}_{3}$, and $\mathrm{C}_{4}$, which fractionate the carbon isotopes differentially, therefore offering a reliable method for paleodiet reconstruction using stable carbon isotope analysis (Vogel and van der Merwe 1977). Plants that follow the $\mathrm{C}_{3}$ photosynthetic pathway have $\delta^{13} \mathrm{C}$ values averaging $\sim 26.5 \%$, while plants that follow the $\mathrm{C}_{4}$ photosynthetic pathway have $\delta^{13} \mathrm{C}$ values averaging $\sim 12.5 \%$ o (Chisholm et al. 1982). The carbon isotopic enrichment between plants and herbivore bone collagen is 2-5\%o (van der Merwe 1982; Balasse et al. 1999; Roth and Hobson 2000).

The stable nitrogen isotopes in terrestrial plants and animals are depleted relative to fish from fresh or marine water habitats (DeNiro 1987). The basic principle of using carbon and nitrogen isotopes in paleodiet determination is based on the observation that the isotope ratios of these elements $\left(\delta^{13} \mathrm{C}\right.$, $\delta^{15} \mathrm{~N}$ ), mainly in collagen, will reflect the corresponding isotopic ratios in the protein of the diet, with adjustment for fractionation through the system (Trimble and Macko 1997). 
$\delta^{15} \mathrm{~N}$ is significantly enriched by $3-5 \%$ in vertebrates relative to their average diet (Post 2002) because they retain ${ }^{15} \mathrm{~N}$ over ${ }^{14} \mathrm{~N}$ during excretion (Sutoh et al. 1987). For a given plant, it depends on the isotopic signature at the base of the food web to which it belongs, and for a herbivore or a predator it depends on the position of the species within the food web (DeNiro and Epstein 1981; Schwarcz and Schoeninger 1991; Bocherens and Drucker 2007). $\delta^{15} \mathrm{~N}$ values of carnivores are approximately $3-5 \%$ higher than the $\delta^{15} \mathrm{~N}$ values of herbivores they consume. Similarly, $\delta^{15} \mathrm{~N}$ values of herbivores are $3-5 \%$ higher than the $\delta^{15} \mathrm{~N}$ values of the plants they consume. The $\delta^{15} \mathrm{~N}$ values of human bone collagen are therefore about $3-5 \%$ higher than the $\delta^{15} \mathrm{~N}$ value of the protein that the human has ingested (DeNiro and Epstein 1981; Ambrose 1993).

Humans that consume only terrestrial protein sources may have collagen $\delta^{13} \mathrm{C}$ values of approximately $-20 \%$, and $\delta^{15} \mathrm{~N}$ values ranging from 5 to $12 \%$, while humans that consume the majority $(>90 \%)$ of their protein from marine food have collagen $\delta^{13} \mathrm{C}$ values close to $-12 \%$ and $\delta^{15} \mathrm{~N}$ values between 12 and 22\%o (Chisholm et al. 1982; Richards et al. 1998; Schoeninger and DeNiro 1984; Schoeninger et al. 1983). On the other hand, humans who consume a mixture of animal and marine protein would have isotopic values somewhere between the above end points.

\section{MATERIALS AND METHODS}

Five molar and 6 femur samples from 7 individuals were taken from 7 tombs: 22, 27, 32, 33, 35, 46A, 46B. One molar and 1 femur sample were taken from each of the 4 individuals buried in tombs $27,32,46 \mathrm{~A}$, and 46B, while 1 molar sample was taken from the individual buried in tomb 33 and 1 femur sample was taken from each of the 2 individuals buried in tombs 22 and 35 . The teeth were well preserved, while the bone fragments were only moderately preserved with only 2 fragments out of 6 producing collagen. The dentine is protected by the enamel, which is less diagenetic compared to bone, nonporous, more crystalline, and has a larger apatite crystalline size (Quade et al. 1992).

The samples were chemically pretreated and dated at the NSF-Arizona Accelerator Mass Spectrometry (AMS) Laboratory following the standard lab protocols. The samples were sonicated in deionized water to remove surface contaminants. After drying, the inner part of the bones and the dentin of the teeth were exposed with a milling bit and then ground (Hodgins and Gann 2005). A 500-600 $\mathrm{mg}$ sample of tooth or bone powder was subjected to a semi-automated, acid-base-acid (ABA) pretreatment system. After the pumping sequence was completed, the ABA-treated bone particles were transferred into borosilicate test tubes and the total solution volume was reduced to $\sim 3 \mathrm{~mL}$. The insoluble "collagen" fraction from the samples was gelatinized at $70^{\circ} \mathrm{C}$ overnight to render it soluble. The gelatinized collagen solutions were filtered through prewashed $0.45-\mu \mathrm{m}$ particle retention glass microfiber filters. The filtrate was recovered and lyophilized in a Speedvac S110 centrifugal evaporator connected to a Varian oil-less Scroll pump. Then, 3-10 mg of the collagen was combusted, graphitized, and finally $\delta^{13} \mathrm{C}$ and ${ }^{14} \mathrm{C}$ were measured, while $2.5 \mathrm{mg}$ of the collagen was used for $\delta^{15} \mathrm{~N}$ and C:N measurements at the Arizona AMS lab using a Fissons Optima isotope ratio mass spectrometer.

\section{EXAMINATION OF DIAGENESIS}

Collagen in fossil bones and teeth may survive for thousands of years in the presence of suitable burial conditions especially in cold and dry climates (Bocherens and Drucker 2007). The evaluation of diagenesis depends on the loss of nitrogen in the sample, but there is not an exchange of elements between soil and collagen, as can be the case with bone apatite. The mechanisms of degradation of collagen involve the gradual breakage of peptide bonds between amino acids, followed by loss of peptides from the collagen triplehelical structure (Collins et al. 1993). The atom to atom ratio of car- 
bon to nitrogen $(\mathrm{C}: \mathrm{N})$ in collagen is about $3: 1$; therefore, a range from 2.9-3.6 is considered acceptable for stable isotope analysis (Ambrose 1990; Bocherens et al. 1996, 1997; DeNiro 1985; Drucker et al. 2001, 2003). The percent total carbon yields from collagen range from about 30 to $45 \%$, and percent total nitrogen yields range from about 11 to 16\% (Ambrose 1990; Bocherens et al. 1996, 1997; Drucker et al. 2003). The previously published literature regarding collagen percent yields for intact bones reported a range from 1 to $20 \%$ (France et al. 2007).

All of the teeth samples and 2 bones (femurs) exhibited the atomic $\mathrm{C}: \mathrm{N}$ ratios and percent yields of collagen within the acceptable rage (Table 1), but the other 4 bone samples were excluded from the study. The collagen yields ranged from $6.1-10.5 \%$, the $\mathrm{C}: \mathrm{N}$ ratios ranged from 3.2 to 3.3 , and the yields of nitrogen and carbon ranged from $11 \%$ to $14.5 \%$ and $29.9 \%$ to $40.1 \%$, respectively.

Table 1 Percentage yields for collagen, carbon $(\mathrm{C})$, and nitrogen $(\mathrm{N})$ and the atomic $\mathrm{C}: \mathrm{N}$ ratios.

\begin{tabular}{lclll}
\hline Sample lab \# & Collagen \% & C\% & N\% & Atomic C:N \\
\hline AA77466 & 9.6 & 40.1 & 14.4 & 3.3 \\
AA77467 & 10.2 & 37.5 & 13.5 & 3.2 \\
AA77468 & 9.6 & 39.9 & 14.4 & 3.2 \\
AA77469 & 9.6 & 29.9 & 11.0 & 3.2 \\
AA77470 & 9.1 & 34.9 & 12.6 & 3.2 \\
AA77475 & 6.1 & 39.7 & 14.5 & 3.2 \\
AA77476 & 10.5 & 30.4 & 11.2 & 3.2 \\
\hline
\end{tabular}

\section{RESULTS AND DISCUSSION}

The AMS ${ }^{14} \mathrm{C}$ dates of the collagen from the samples are presented in Table 2 . The ${ }^{14} \mathrm{C}$ ages of the individual buried in tomb 32 are the oldest, while those buried in tomb 27 are apparently the youngest. Tooth and bone dates overlap and are generally assigned to the Early Roman period. ${ }^{14} \mathrm{C}$ dates agree with the historical and archaeological dates of the site derived from the typology of the tombs and grave good data (El-Najjar et al. 2008).

Table $2{ }^{14} \mathrm{C}$ dates, $\delta^{13} \mathrm{C}$, and $\delta^{15} \mathrm{~N}$ values (Unkn = unknown; ${ }^{*}=$ same individual).

\begin{tabular}{llllllll}
\hline Sample lab \# & Material & Sex & Age & Tomb nr & ${ }^{14} \mathrm{C}$ age BP & $\delta^{13} \mathrm{C}$ & $\delta^{15} \mathrm{~N}$ \\
\hline AA77466 & Tooth molar & Unkn & $<35$ & $46 \mathrm{~A}$ & $1891 \pm 46$ & $-19.6 \pm 0.1$ & $9.0 \pm 0.20$ \\
AA77467 & Tooth molar & M & Adult & 27 & $1842 \pm 46$ & $-19.7 \pm 0.1$ & $8.6 \pm 0.20$ \\
AA77468 & Tooth molar & $\mathrm{F}$ & $35-50$ & $32^{*}$ & $2007 \pm 46$ & $-18.7 \pm 0.1$ & $8.7 \pm 0.20$ \\
AA77469 & Tooth molar & $\mathrm{F}$ & $20-35$ & 33 & $1947 \pm 46$ & $-19.3 \pm 0.1$ & $9.0 \pm 0.20$ \\
AA77470 & Tooth molar & M & $>35$ & $46 \mathrm{~B}$ & $1958 \pm 46$ & $-19.3 \pm 0.1$ & $8.8 \pm 0.08$ \\
AA77475 & Bone femur & $\mathrm{F}$ & $35-50$ & $32^{*}$ & $2060 \pm 47$ & $-19.1 \pm 0.1$ & $8.8 \pm 0.11$ \\
AA77476 & Bone femur & Unkn & Adult & 22 & $2032 \pm 50$ & $-19.2 \pm 0.1$ & $8.5 \pm 0.11$ \\
\hline
\end{tabular}

The values of $\delta^{13} \mathrm{C}$ and $\delta^{15} \mathrm{~N}$ are shown in Table 2. The $\delta^{13} \mathrm{C}$ values range between $-19.7 \pm 0.02$ and $-18.7 \pm 0.015$. Based on these values and that the enrichment factor of human collagen of around $5 \%$ for carbon (DeNiro 1985), the average $\delta^{13} \mathrm{C}$ of $-19.4 \pm 0.026$ of all samples indicates a diet with protein sources from $\mathrm{C}_{3}$ plants, and/or animals that consumed $\mathrm{C}_{3}$ plants. The values also show that there was minimal (if any) effect of marine food sources or $\mathrm{C}_{4}$ protein on the diet. Significant quantities of Marine food would have caused a much less negative $\delta^{13} \mathrm{C}$ value. 
The samples showed a relationship between dates and $\delta^{13} \mathrm{C}$ values, where the correlation coefficient is 0.96 at a $p$ value of 0.05 ; the sample of older age is less negative in the $\delta^{13} \mathrm{C}$ value (see Figure 2 and Table 2).

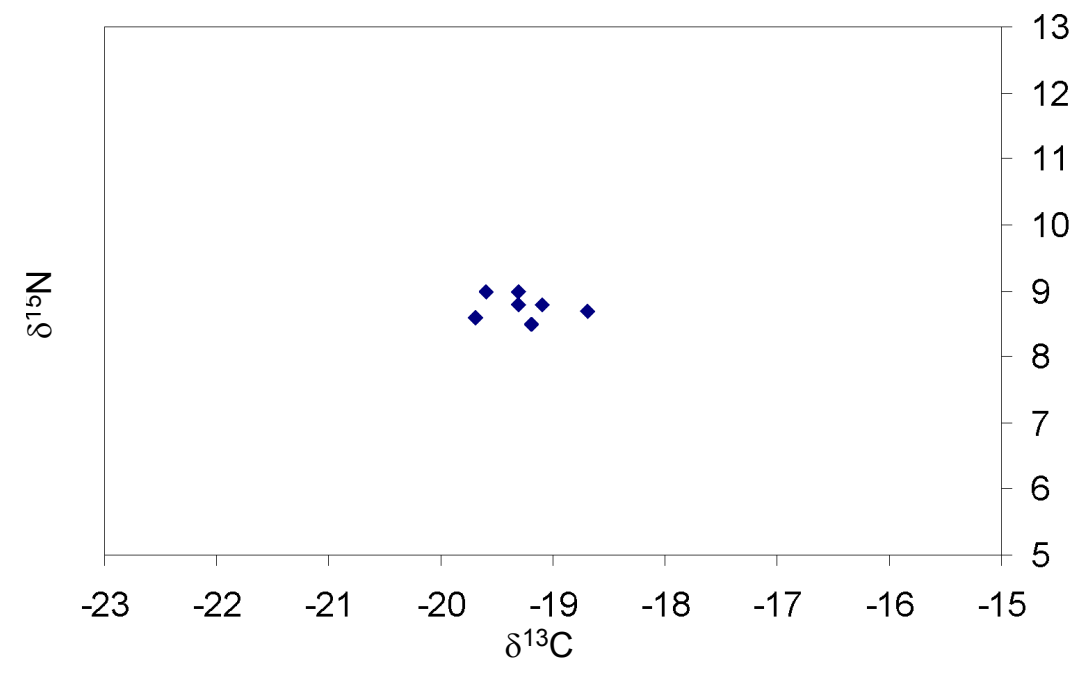

Figure 2 Plot of $\delta^{13} \mathrm{C}$ and $\delta^{15} \mathrm{~N}$ collagen values

The values of $\delta^{15} \mathrm{~N}$ range from $8.5 \%$ to $9 \%$ (the average is $8.8 \pm 0.16 \%$ ), indicating a diet dependent upon terrestrial animal proteins, e.g. meat, milk, dairy products, and eggs. Bourbou and Richards (2005) measured carbon and nitrogen stable isotopes of bone collagen from the Middle Byzantine site of Kastella, in the city of Heraklion on the island of Crete, Greece. They interpreted their data derived from the analysis $\left(\delta^{13} \mathrm{C}\right.$ ranged between $-18.2 \%$ and $-19.4 \%, \delta^{15} \mathrm{~N}$ ranged between $7.5 \%$ and $11.6 \%$ ) as a diet based primarily on terrestrial animal protein, probably from animal sources, with some marine protein.

The isotope signatures have not detected differences in diet of the individuals in Natfieh and probably indicate a similar social status. All of the buried individuals (males, females, adults, and young) in these tombs had similar diets, which throws doubt on the hypothesis of El-Najjar et al. (2008) about the higher social status. The 2 individuals of tombs 46A and 46B did not differ in their diet from the other individuals of the rest of the tombs.

Al-Shorman (2004) studied the ancient diet of the Middle/Late Bronze Age at Ya'amoun in northern Jordan and showed that $\mathrm{C}_{3}$ plants were the major component of the paleodiet. The similarity of our results to Al-Shorman's (2004) result might be due to a continuity of $\mathrm{C}_{3}$ food consumption from the Bronze Age to the Roman period in northern Jordan. Similar results and conclusions were achieved by King (2001) who analyzed the stable carbon and nitrogen ratios of teeth from the Late Roman/ Byzantine sites of Sa'ad, Ya'amoun, and Yasileh (northern Jordan) to test for differences in their diet and to compare the diets of these sites to that of the Late Bronze Age people from Ya'amoun.

Prowse et al. (2004) studied collagen and bone apatite samples from individuals buried in the 1st3rd centuries AD cemetery of Isola Sacra on the Mediterranean coast near Rome, Italy. They compared collagen data to a smaller skeletal sample from the nearby inland site of ANAS. Individuals from the ANAS site displayed isotopic compositions consistent with a terrestrial-based diet, while 
many of the skeletons from Isola Sacra were more enriched in $\delta^{15} \mathrm{~N}$ and, to a lesser extent, in $\delta^{13} \mathrm{C}$. The $\delta^{13} \mathrm{C}$ data from Isola Sacra ranged from $-17.8 \%$ to $-19.7 \%$ and $\delta^{15} \mathrm{~N}$ data from $7.5 \%$ to $14.4 \%$, while the $\delta^{13} \mathrm{C}$ data from ANAS ranged from $-18.8 \%$ to $-20.0 \%$ and $\delta^{15} \mathrm{~N}$ data ranged from $6.9 \%$ to $11.3 \%$. The higher $\delta^{15} \mathrm{~N}$ of the people from the Isola Sacra samples indicates that they were consuming higher trophic foods than some of the people buried at the ANAS cemetery.

The site of Natfieh is an inland site, $\sim 110 \mathrm{~km}$ from the Mediterranean shoreline and $30 \mathrm{~km}$ away from Lake Tiberias. Fish from Lake Tiberias were a widely traded luxury item. Because fish were considered an expensive food item during the Roman period, the regular consumption of fish may have been restricted to elite members of society (Frayn 1993); the people of Natfieh might have not accessed protein sources from marine food and freshwater fish.

The interpretation of the diet suggested from the isotopic analyses agrees with the Roman historical records about diet that have been discussed elsewhere (Prowse et al. 2004; Keenleyside et al. 2009). Historical accounts of Roman diet repeatedly refer to grains as the base of the Roman diet. It depended mainly on terrestrial food resources including wheat, barley, cereals, olive oil, and wine, together with legumes including broad beans, lentils, and peas. Cheese made from goat and sheep milk was a popular food item, while meat (mainly pork) was considered a prestigious food and an important component of the diet among members of the upper social class. Although fish sauce, such as garum, was widely mentioned in ancient recipes (Curtis 1991) and might have added a marine signature to the diet since marine fish are used to make the sauce, it is not clear if it was consumed in this rural site in significant quantities.

\section{CONCLUSION}

Based on the stable isotope evidence presented here, it seems obvious that agriculture and animal husbandry were the sources of food for the individuals buried at the site of Natfieh. The geographical location of the site of Natfieh restricted access to marine food and the distance from the major trade routes and cities limited the possibility of long-distance trade in foods. Although the site was small, rural, and inhabited by peasants, the quality of the consumed diet seemed able to maintain the general well-being of the inhabitants during this period of occupation. In addition to the coercive power of the society in the form of regular taxes that had to be paid, the people of Natfieh during the Roman period had fewer opportunities to diversify their subsistence economy and, thus, adjusted to the local and self-sufficient agricultural economy.

\section{ACKNOWLEDGMENTS}

We would like to acknowledge the contributions of the NSF-Arizona AMS facility. Some of this work was completed while the first author was a PhD student at the University of Arizona. This work was supported in part by NSF grant EAR0622305. We acknowledge Prof Douglas Price for reviewing the manuscript and Mr Faris Bdeer for his help in collecting the samples.

\section{REFERENCES}

Al-Shorman A. 2004. Stable carbon isotope analysis of human tooth enamel from the Bronze Age cemetery of Ya'amoun in Northern Jordan. Journal of Archaeological Science 31(12):1693-8.

Ambrose SH. 1990. Preparation and characterization of bone and tooth collagen for isotopic analysis. Journal of Archaeological Science 17(4):431-51.

Ambrose S. 1993. Isotopic analysis of paleodiets: meth- odological and interpretive considerations. In: Sandford MK, editor. Investigations of Ancient Human Tissue: Chemical Analyses in Anthropology. Langhorne: Gordon and Breach Science Publishers. p 59-130.

Ambrose S, Norr L. 1993. Experimental evidence for the relationship of the carbon isotope ratios of whole diet and dietary protein to those of bone collagen and carbonate. In: Lambert JB, Grupe G, editors. Prehistoric 
Human Bone: Archaeology at the Molecular Level. New York: Springer-Verlag. p 1-37.

Balasse M, Bocherens H, Mariotti A. 1999. Intra-bone variability of collagen and apatite isotopic composition used as evidence of a change of diet. Journal of Archaeological Science 26(6):593-8.

Bocherens HM, Drucker DG. 2007. Carbonate stable isotopes/terrestrial teeth and bones. In: Elias SA, editor. Encyclopedia of Quaternary Science. Amsterdam: Elsevier. p 309-17.

Bocherens H, Pacaud G, Lazarev PA, Mariotti A. 1996. Stable isotope abundances $\left({ }^{13} \mathrm{C},{ }^{15} \mathrm{~N}\right)$ in collagen and soft tissues from Pleistocene mammals from Yakutia: implications for the palaeobiology of the Mammoth Steppe. Palaeogeography, Palaeoclimatology, Palaeoecology 126(1-2):31-44.

Bocherens H, Billiou D, Patou-Mathis M, Bonjean D, Otte M, Mariotti A. 1997. Paleobiological implications of the isotopic signatures $\left({ }^{13} \mathrm{C},{ }^{15} \mathrm{~N}\right)$ of fossil mammal collagen in Scladina Cave (Sclayn, Belgium). Quaternary Research 48(3):370-80.

Bourbou C, Richards MP. 2005. The Middle Byzantine menu: palaeodietary information from isotopic analysis of humans and fauna from Kastella, Crete. International Journal of Osteoarchaeology 17(1):63-72.

Chisholm BS, Nelson DE, Schwarcz HP. 1982. Stable carbon isotope ratios as a measure of marine versus terrestrial protein in ancient diets. Science 216(4550): 1131-2.

Collins MJ, Riley MS, Child AM, Turner-Walker G. 1993. A basic mathematical simulation of the chemical degradation of ancient collagen. Journal of Archaeological Science 22(2):175-84.

Curtis RI. 1991. Garum and Salsamenta. New York: E.J. Brill. $336 \mathrm{p}$.

DeNiro MJ. 1985. Postmortem preservation and alteration of in vivo bone collagen isotope ratios in relation to palaeodietary reconstruction. Nature 317(6040): 806-9.

DeNiro MJ. 1987. Stable isotopy and archaeology. American Scientist 75(2):182-91.

DeNiro MJ, Epstein S. 1981. Influence of diet on the distribution of nitrogen isotopes in animals. Geochimica et Cosmochimica Acta 45(3):341-51.

Drucker D, Bocherens H, Pike-Tay A, Mariotti A. 2001. Isotopic tracking of seasonal dietary change in dentine collagen: preliminary data from modern caribou. Comptes Rendus de l'Académie des Sciences - Series IIA - Earth and Planetary Science 333(5):303-9.

Drucker D, Bocherens H, Bridault A, Billiou D. 2003. Carbon and nitrogen isotopic composition of red deer (Cervus elaphus) collagen as a tool for tracking palaeoenvironmental change during the Late-Glacial and Early Holocene in the northern Jura (France). Palaeogeography, Palaeoclimatology, Palaeoecology 195(3):375-88.

El-Najjar MJ, Rose JC, Al-Bataineh M. 2008. Newsletter of the Faculty of Archaeology and Anthropology
(Yarmouk University) 27/28:9-11.

Finley M. 1999. The Ancient Economy. Berkeley: University of California Press. 298 p.

France CAM, Zelanko PM, Kaufman AJ, Holtz TR. 2007. Carbon and nitrogen isotopic analysis of Pleistocene mammals from the Saltville Quarry (Virginia, USA): implications for trophic relationships. Palaeogeography, Palaeoclimatology, Palaeoecology 249(3-4):271-82.

Frayn JM. 1993. Markets and Fairs in Roman Italy. Oxford: Clarendon Press. $183 \mathrm{p}$.

Freeman P. 2001. Roman Jordan. In: MacDonald B, Adams R, Bienkowski P, editors. The Archaeology of Jordan. Sheffield: Sheffield Academic Press. p 44052.

Grossman G. 1974. Economic Systems. Englewood Cliffs: Prentice Hall Inc. 195 p.

Hodgins GWL, Gann JP. 2005. A new semi-automated acid-base-acid extraction system for radiocarbon samples. Poster presented at the 10th International Conference on Accelerator Mass Spectrometry, Berkeley, California, USA. 5-10 September 2005.

Keenleyside A, Schwarcz H, Stirling L, Ben Lazreg N. 2009. Stable isotopic evidence for diet in a Roman and Late Roman population from Leptiminus, Tunisia. Journal of Archaeological Science 36(1):51-63.

King MJ. 2001. Analysis of diet in Byzantine Jordan: isotopic evidence in human dentine [unpublished Master's thesis]. Anthropology Department, University of Arkansas, Fayetteville, Arkansas, USA.

Kingsley S. 2001. The economic impact of the Palestinian wine trade. In: Kingsley S, Decker M, editors. Late Antiquity Economy and Exchange in the East Mediterranean during Late Antiquity. Oxford: Oxbow Books. p 44-68.

Post D. 2002. Using stable isotopes to estimate trophic position: models, methods, and assumptions. Ecology 83(3):703-18.

Prowse TL, Schwarcz HP, Saunders SR, Macchiarelli R, Bondioli L. 2004. Isotopic paleodiet studies of skeletons from the Imperial Roman-age cemetery of Isola Sacra, Rome, Italy. Journal of Archaeological Science 31(3):259-72.

Quade J, Cering TE, Barry JC, Morgan ME, Pilbeam DR, Chivas AR, LeeThorp JA, van der Merwe NJ. 1992. A 16-Ma record of paleodiet using carbon and oxygen isotopes in fossil teeth from Pakistan. Chemical Geology 94(3):183-92.

Richards MP, Molleson TI, Vogel JC, Hedges REM. 1998. Stable isotope analysis reveals variations in human diet at the Poundbury Camp Cemetery site. Journal of Archaeological Science 25(12):1247-52.

Rose JC, El-Najjar MJ, Burke DL. 2007. Trade and the acquisition of wealth in rural Late Antique north Jordan. In: al-Khraysheh F, editor. Studies in the History and Archaeology of Jordan IX. Amman: Department of Antiquities. p 61-70.

Roth JD, Hobson KA. 2000. Stable carbon and nitrogen 
isotopic fractionation between diet and tissue of captive red fox: implications for dietary reconstruction. Canadian Journal of Zoology 78:848-52.

Schoeninger MJ, DeNiro MJ. 1984. Nitrogen and carbon isotopic composition of bone collagen from marine and terrestrial animals. Geochimica et Cosmochimica Acta 48(4):625-39.

Schoeninger M, DeNiro M, Tauber H. 1983. Stable nitrogen isotope ratios of bone collagen reflect marine and terrestrial components of prehistoric human diet. Science 220(4604):1381-3.

Schwarcz HP, Schoeninger M. 1991. Stable isotope analyses in human nutritional ecology. Yearbook of Physical Anthropology 34:283-321.

Sealy J. 2001. Body tissue chemistry and palaeodiet. In: Brothwell DR, Pollard AM, editors. Handbook of Archaeological Sciences. Chichester: John Wiley \& Sons Inc. p 269-79.

Sutoh M, Koyama T, Yoneyama T. 1987. Variations of natural ${ }^{15} \mathrm{~N}$ abundances in the tissues and digesta of domestic animals. Radioisotopes 36(2):74-7.

Thompson AH, Richards MP, Shortland A, Zakrzewski SR. 2005. Isotopic palaeodiet studies of ancient Egyptian fauna and humans. Journal of Archaeological Science 32(3):451-63.

Tieszen L, Fagre T. 1993. Effect of diet quality and com- position on the isotopic composition of respiratory $\mathrm{CO}_{2}$, bone collagen, bioapatite, and soft tissues. In: Lambert JB, Grupe G, editors. Prehistoric Human Bone: Archaeology at the Molecular Level. New York: Springer-Verlag. p 121-55.

Toynbee JMC. 1996. Death and Burial in the Roman World. Baltimore: Johns Hopkins University Press. $336 \mathrm{p}$.

Trainter J. 1975. Social inferences and mortuary practice: an experiment in numerical classification. World $\mathrm{Ar}$ chaeology 7(1):1-15.

Trimble CC, Macko SA. 1997. Stable isotope analysis of remains: a tool for cave archaeology. Journal of Cave and Karst Studies 59(3):137-42.

Tykot RH. 2006. Isotope analyses and the histories of maize. In: Staller JE, Tykot RH, Benz BF, editors. Histories of Maize: Multidisciplinary Approaches to the Prehistory, Linguistics, Biogeography, Domestication, and Evolution of Maize. New York: Academic Press-Elsevier. p 131-42.

van der Merwe NJ. 1982. Carbon isotopes, photosynthesis, and archaeology. American Scientist 70:596-606.

Vogel JC, van der Merwe NJ. 1977. Isotopic evidence for early maize cultivation in New York State. American Antiquity 42(2):238-42. 